Journal of Applied Pharmaceutical Science Vol. 7 (03), pp. 175-179, March, 2017

Available online at http://www.japsonline.com

DOI: $10.7324 / J A P S .2017 .70328$

ISSN 2231-3354 (cc) BY-NC-SA

\title{
In Vitro Cytotoxic Activity of Laurencia papillosa, Marine Red Algae from the Lebanese Coast
}

\author{
Mona Y. Tannoury ${ }^{1,2}$, Antoine M. Saab ${ }^{3 *}$, Josiane M. Elia ${ }^{1}$, Nafez N. Harb ${ }^{4}$, Hassane Y. Makhlouf ${ }^{1}$, Mona Diab-Assaf ${ }^{2,3}$ \\ ${ }^{1}$ Department of Biology, Faculty of Sciences II, Lebanese University, Lebanon. ${ }^{2}$ Doctoral School of Science and Technology, Lebanese University, \\ Lebanon. ${ }^{3}$ Department of Chemistry, Faculty of Sciences II, Lebanese University, Lebanon. ${ }^{4}$ Department of Biology, Faculty of Sciences III, Lebanese \\ University, Lebanon.
}

\author{
ARTICLE INFO \\ Article history: \\ Received on: 12/12/2016 \\ Accepted on: 30/01/2017 \\ Available online: 30/03/2017 \\ Key words: \\ Red algae; Laurencia \\ papillosa; cytotoxic activity; \\ Jurkat; trypan blue exclusion \\ test.
}

\begin{abstract}
Marine algae are an excellent source of bioactive compounds with a variety of biological activities. This paper presents a study on the cytotoxic activity of Laurencia papillosa (Rhodomelaceae), marine red algae collected at the Lebanese coast against the human cancer cell line Jurkat (acute lymphoblastic leukemia) through the trypan blue exclusion assay. The results show that the percentage of cell viability was reduced by increasing the concentration of both algal extracts: ethanol/ water extract, and ethanol/ chloroform extract. The ethanol/ chloroform extract exhibits the highest levels of cytotoxicity with IC50 value of $57.77 \mu \mathrm{g} / \mathrm{mL}$ against Jurkat cancer cell line especially after 72 hours of treatment compared with the ethanol/water extract with IC50 value of $121.642 \mu \mathrm{g} / \mathrm{mL}$. Further research should be explored in order to study the bioactive compounds of Laurencia papillosa that could be potentially useful therapeutic agents for patients with acute lymphoblastic leukemia.
\end{abstract}

\section{INTRODUCTION}

Cancer is one of the most serious diseases that threaten the human health all over the world. According to the type of abnormal white blood cells involved, and depending on the rate of proliferation of leukemia cells, leukemia, also known as blood cancer, is divided into four main groups: acute lymphocytic, chronic lymphocytic, acute myeloid, and chronic myeloid (Pieters et al., 2008). Acute lymphoblastic leukemia which is a malignant disorder of lymphoid progenitor cells, presents the most common type of childhood cancer. Jurkat cells may be used to study T-lymphocyte behavior, cell signaling, and expression of chemokine receptors. They are also important in producing interleukin 2. The Jurkat cell line was established in the late 1970s from the peripheral blood of a 14- year- old boy with $\mathrm{T}$ cell leukemia. Different derivatives of the Jurkat cell line can be

* Corresponding Author

Dr. Antoine Saab, Department of Chemistry, Faculty of Sciences II, Lebanese University,Lebanon.E-mail: antsaab@gmail.com now obtained from cell culture banks that have been mutated to lack certain genes (Hu et al., 2015). Regarding the resistance of cancer cells to currently used antitumor drugs, finding new, safe, and effective anticancer drugs with fewer side effects has become a need for many scientists (Ross, 2000). There has been a lot of attention to natural compounds obtained from marine algae to discover their medicinal and pharmaceutical properties such as anticancer, antibacterial, and antioxidant effects (Smit, 2004). Long time ago, and in many Asian countries especially China and Japan, the marine algae were used as functional foods and medicinal herbs because of their richness in lipids, minerals, vitamins, and bioactive substances like polysaccharide, protein, and polyphenol (Namvar et al., 2013). Because some types of algae were used to treat cancer, many crude extract and compounds derived from various algae have been tested for their antitumor activities (Mohamed et al., 2012). These studies have pointed out that marine algae form a promising source of bioactive compounds as human therapeutic agents. Laurencia is a genus of marine red algae, Rhodophyta division, Ceramiales order, and Rhodomelaceae family, that mostly lives in tropical oceans (Cabioc'h, 1992). 
The marine red algae Laurencia is a more diverse group with about 140 species of algae (Kim et al., 2013). This genus is a prolific synthesizer of halogenated metabolites, capable of producing more than 250 different compounds (Kim et al., 2013). They are among the most prolific producers of secondary metabolites in the marine environment (Vieira et al., 2015), including sesquiterpenes, diterpenes, triterpenes and many other types. Those compounds have various biological activities such as antifungal, antibacterial, and anticancer activities (Kladi et al., 2006). Several researchers have studied the antiproliferative as well as the cytotoxicity action of the crude extracts and compounds derived from Laurencia vis a vis different cancer cell lines. A sesquiterpene, the elatol (0.1-100 $\mu \mathrm{M})$ isolated from Laurencia microcladia by Campos el al. (2012) shows an anticancer effect by reducing cell viability of B16F10 (melanoma murine), A549 (human lung carcinoma), DU145 (carcinoma of human prostate), L929 (mouse fibroblasts), and MCF-7 (human breast adenocarcinoma). In addition, treatment with elatol was able to reduce tumor growth in vivo in mice inoculated by B16F10 cells (Campos et al., 2012). Another study indicates that the polyether of Laurencia viridis has cytotoxic activity against human cancer cell lines Jurkat (acute T cell leukemia), MM144 (myeloma), HeLa (cervix adenocarcinoma), and CADO-ES1 (Ewing sarcoma human). It is worth noting here that leukemic Jurkat cells were more sensitive to polyether compounds tested with an IC 50 values of 2.0-3.5 $\mu \mathrm{M}$ (Pacheco et al., 2011). These two compounds, the sesquiterpene of L. microcladia (Campos et al., 2012) and the polyether of L. viridis (Pacheco et al., 2011), also show a proapoptotic effect to the cells B16F10 and Jurkat, respectively. This effect is triggered by various changes such as a decreased expression of anti-apoptotic proteins $\mathrm{Bcl}-\mathrm{xL}$, an increased expression of pro-apoptotic proteins Bak, and an activation of caspase 9 (Campos et al., 2012). The increase in apoptotic population sub-G0 phase was another indication of the induction of apoptosis (Pacheco et al., 2011; Campos et al., 2012). In addition, the sesquiterpene isolated from Laurencia microcladia increases the expression of p53 tumor suppressor gene in the B16F10 cells (Campos et al., 2012).

The brominated diterpenes isolated from the organic extract of Laurencia obtusa exhibited cytotoxicity against five human cell lines: MCF7 (breast), PC3 (prostate), HeLa (cervix), A431 (epidermis), and K562 (myelogenic) (Iliopoulou et al., 2003). Moreover, the laurene-type sesquiterpenes isolated from the organic extract of Laurencia obtusa were evaluated for their antitumor activity in an in vitro model of Ehrlich ascites Carcinoma (Alarif et al., 2012). The Ehrlich ascites in vitro assay shows that this laurene sesquiterpene had a cytotoxic activity.

Furthermore, Zaleta-Pinet et al. (2014) reported that some compounds isolated from ethanol extract of Laurencia pacifica $(25 \mu \mathrm{M})$ were cytotoxic against a panel of cancer cell lines HT29 (colon), U87, SJ-G2 (glioblastoma), MCF-7 (breast), A2780 (ovary), H460 (lung), A431 (skin), DU145 (prostate), BE2$\mathrm{C}$ (neuroblastoma), MIA (pancreas), ADM (murine glioblastoma) and MCF10A (normal breast cell line) (Zaleta-Pinet et al., 2014).
In addition, Kladi et al. (2006) highlight the cytotoxicity of isolated metabolites from Laurencia obtusa and Laurencia microcladia against various human tumor cell lines: K562 (chronic myelogenous leukemia), MCF7 (breast adenocarcinoma), PC3 (prostate adenocarcinoma), HeLa (carcinoma of the cervix), A431 (carcinoma squamous), A549 NSCLC-N6 (lung cancer), and CHO cells which are a cell line derived from the ovaries of a Chinese hamster, by a MTT test (Kladi et al., 2006).

In this study, we prepared ethanol: water (50: 50; V/V) and ethanol: chloroform (50: 50; V/V) crude extracts from the marine red algae Laurencia papillosa collected from the Lebanese coast. The main objective is to evaluate their cytotoxic activity on the human cancer cell line Jurkat through the trypan blue exclusion assay.

\section{MATERIALS AND METHODS}

\section{Chemicals}

Chemicals and reagents used to study anti-proliferative activities were purchased from Sigma-Aldrich Co. (Beirut, Lebanon) while the other chemicals, solvents, and reagents were purchased from Alpha Co. (Beirut, Lebanon). The fetal bovine serum was the only chemical obtained from CELBIO (Milano, Italy).

\section{Plant materials}

The marine red algae L. papillosa was manually collected from El Barbara beach in Lebanon at the end of May 2015. The collected samples were transported to the laboratory where they were first washed thoroughly with fresh water to remove slats, sand, and epiphytes, then with hydrochloric acid $10 \%$ for a few seconds to remove the organic matter, and finally with distilled water. Then, the algae were frozen at $-80^{\circ} \mathrm{C}$ and lyophilized. After drying, the algae were ground to powder in a blender. Voucher specimen No 700 was botanically authenticated by Dr. Mona Tannoury, Biology Department, Faculty of Sciences II, Lebanese University and deposited in the Biology Department Herbarium, Faculty of Sciences II, Lebanese University.

\section{Sample extraction}

The dried and ground sample $(2 \mathrm{~g})$ of $L$. papillosa was dissolved in $40 \mathrm{~mL}$ of ethanol: water (v: v) by maceration during 24 hrs. The material was filtered by using Whatman paper No 1 , whereas the extract plant was transferred to $50 \mathrm{ml}$-round-bottom flask, and then taken with rotary vacuum evaporator. Moreover, these crude extracts were freeze-dried by lyophilization. While another dried and ground sample ( 2 gms) of $L$. papillosa was extracted with chloroform: ethanol by maceration similar to the extraction of ethanol: water protocol (Choi et al., 2004).

\section{Cell lines and culture condition}

Jurkat cells ( $\mathrm{T}$ lymphocyte cells): The cells are suspended lymphoblasts. The growth medium was Advanced RPMI 1640 (Gibco/Invitrogen), 10\% fetal bovine serum 
(Hyclone), $10 \mathrm{mM}$ Hepes $100 \mathrm{U} / \mathrm{mL}$ penicillin, and $100 \mu \mathrm{g} / \mathrm{mL}$ streptomycin, $5 \% \mathrm{CO}_{2}\left(37^{\circ} \mathrm{C}\right)$. Liquid Nitrogen Storage: Complete growth medium supplemented with $5 \%(\mathrm{v} / \mathrm{v})$ DMSO in $1 \mathrm{~mL}$ aliquots of approximately $5 \times 10^{6}$ cells. RPMI 1640 medium for suspension cells with fetal bovine serum (FBS) (Lampronti et al., 2006; Saab et al., 2011).

\section{Cell viability assay}

Jurkat cells $(20,000$ cells/ dish) were seeded in 24-well plates. Two wells were prepared for each concentration. The cells treated with $L$. papillosa at different concentrations were compared with untreated controls. Besides, Jurkat cells were treated with ethanol: water $L$. papillosa extract at different concentrations as well as chloroform: ethanol: L. papillosa extract. The plates were incubated for 3 days. The cytotoxicity was determined by trypan blue staining. The cell suspension $(20 \mathrm{~mL})$ was taken from the well and mixed with $20 \mathrm{~mL}$ trypan blue. The living cells weren't stained and can be easily distinguished from the blue dead cells which absorbed the dye because of their damaged membrane. Then, $10 \mathrm{~mL}$ of this mixture were used for cell counting (Esseily et al.,2012).

\section{Statistical analysis}

All experiments were carried out in triplicate. The data were expressed as means $\pm \mathrm{SD}$ and the differences were evaluated by one-way analysis of variance (ANOVA) test completed by Dunnett's test. The differences were considered significant at $* * p$ $<0.01$. The $50 \%$ inhibitory concentration $\left(\mathrm{IC}_{50}\right)$ was calculated by nonlinear regression curve with the use of Prism Graphpad Prism version 4.0 for Windows [GraphPad Software, San Diego, CA, USA (Hwww.graphpad.com)H].

\section{RESULTS AND DISCUSSION}

The yields of ethanol: water and ethanol: chloroform extracts of Laurencia papillosa relative to the initial amount of dry seaweed were determined. The result shows that the best yield is for the water: ethanol extract with a value of $27.386 \%$, and the low yield of $3.433 \%$ is for the ethanol: chloroform extract.

In order to evaluate the ethanol: chloroform extract and the ethanol: water extract prepared from the red algae Laurencia papillosa collected from the Lebanese coast, Jurkat cancer cells were seeded at initial cell concentration 20,000 cells/ $\mathrm{mL}$ and then cultured for 3 days either in the presence or absence of $L$. papillosa extracts at concentrations ranging from $25-1000 \mu \mathrm{g} / \mathrm{mL}$.

The trypan blue exclusion assay, intended to count the viable cells after exposure to different concentrations of extract, is summarized in (Fig. 1 and 2). Based on these data, it was shown that the number of Jurkat cells in the negative control wells (without extract) increased after 24, 48, and 72 hours of treatment. Besides, the number of the viable cells is decreased with the increase in concentration of both algal extracts, ethanol: water and ethanol: chloroform extracts, from 25 to $1000 \mu \mathrm{g} / \mathrm{mL}$, after 24,48 and 72 hours of treatment. Thus, the cytotoxicity of the two $L$. papillosa crudes extracts against Jurkat cells depends on time and dose. The ethanol: chloroform extract with IC50 value of 57.77 $\mu \mathrm{g} / \mathrm{mL}$ is more cytotoxic than the ethanol: water extract with IC50 value of $121.642 \mu \mathrm{g} / \mathrm{mL}$, after $72 \mathrm{~h}$ of treatment. According to this result, we notice that the cytotoxicity of Laurencia papillosa crude extracts also depends on the choice of the extraction solvent against human leukemic cell lines Jurkat. Indeed, many studies have assessed the cytotoxic activity of other algae species of the genus Laurencia. A comparative study was carried out in order to examine the cytotoxic properties of extracts obtained from a group of Laurencia (L. aldingensis, L. catarinensis, L. dendroidea, L. intricata, L. translucida, L. sp, and Palisada flagellifera) against MES-SA cells (human uterine sarcoma) (Stein et al., 2011).

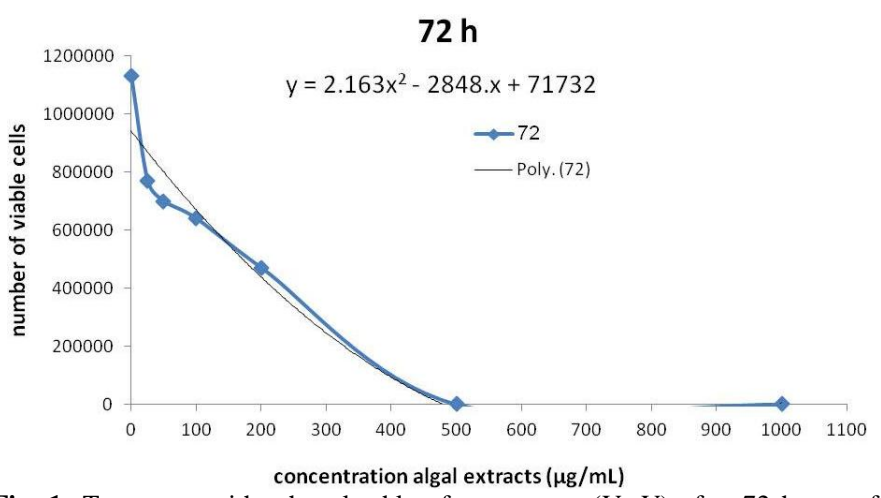

Fig. 1: Treatment with ethanol: chloroform extract (V: V) after 72 hours of treatment.

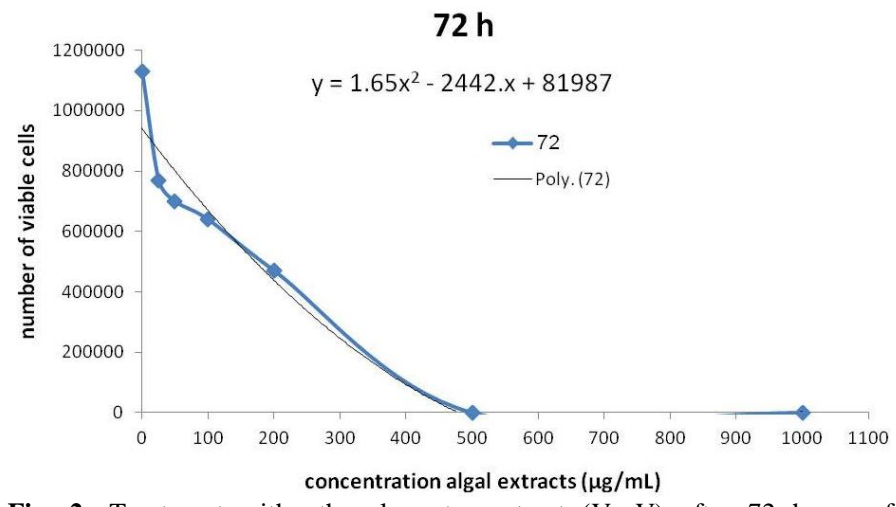

Fig. 2: Treatment with ethanol: water extract (V: V) after 72 hours of treatment.

The high level of cytotoxicity was marked for the hexane extract (hexane being a non polar solvent) with over $80 \%$ of cell mortality, while the low level of cytotoxicity was recorded for the methanol extract (methanol being a polar solvent) with $30 \%$ of cell death. Many halogenated metabolites isolated from the organic extract of Laurencia catarinensis were evaluated for their in vitro cytotoxic activity against HT29, MCF7, and A431 human tumor cell lines. Certain compounds were found to be much more active among all evaluated metabolites with IC50 values lower than 20 $\mu \mathrm{M}$ (Lhullier et al,. 2010). Furthermore, an arabinopyranoside isolated from Laurencia majuscula had an antitumor activity in 
LOVO (human colon adenocarcinoma) and Bel-7402 (hepatocellular carcinoma) cell lines (Du et al., 2010). The IC50 of arabinopyranoside treatment on LOVO and Bel-7402 cells was $15.82 \mu \mathrm{g} / \mathrm{mL}$ and $11.5 \mu \mathrm{g} / \mathrm{mL}$, respectively. Western blotting and Flow cytometric analysis demonstrated that the arabinopyranoside was also able to arrest the cell cycle in the G2/M phase.

On the other hand, a diterpene and several sesquiterpenes were isolated from the organic extract of Laurencia obtusa and their cytotoxicity were evaluated against mammalian cell lines KB, HepG2, and MCF-7 (Angawi et al., 2014). First, the MTT test showed a moderate activity of the diterpene towards $\mathrm{KB}$ and MCF-7 cells with $\mathrm{IC}_{50}$ values of 0.171 and $0.184 \mu \mathrm{m}$, respectively. One of the isolated sesquiterpenes also had a moderate activity against $\mathrm{KB}$ at a concentration of $0.213 \mu \mathrm{g} / \mathrm{ml}$, while another sesquiterpene exhibited a broad range of cytotoxic activity against $\mathrm{KB}$, HepG2, and MCF-7 with IC50 of $0.100,0.057$, and 0.054 $\mu \mathrm{M}$, respectively.

\section{Ethno botanicals and medical uses}

Marine algae open numerous perspectives for research and for many economic sectors. They are primarily consumed as vegetables, mainly in Asian countries (Kandale et al., 2011). They usually consist of proteins, a small amount of fat compared to the percentage of carbohydrates, which are mainly in the form of polysaccharides such as alginates, carrageenan and ulvans. In addition they contain high levels of minerals, vitamins and pigments (Makkar et al., 2016). They are a potential source of food supplements due to the diversity of molecules which gives them multiple nutritional qualities. Alginates, carrageenans and agars are the major industrial products derived from algae. The extraction of these phycocolloids is used in the food industry (gelling agents), pharmaceuticals (dressings, coatings of medicaments) and biotechnology (culture medium, the Petri dishes). They are also found in cosmetics (body lotions, soaps, shampoos, toothpaste), and even in industrial products (adhesives, paints for building) (Person, 2011). Marine algae have traditionally been used in animal feed. Today, algae are found in the form of flour, and constitute a primary source of nutrients for many animal species. They are also used in agriculture (Kandale et al., 2011; Makkar et al., 2016) (fertilizer / bio-fertilizers, phytosanitary treatments to promote the growth of leaves and stems, plant protection against certain diseases), and as well as a bio-based materials (home textiles, adhesives, cements and mortars, antifouling paints for ships, paper and cardboard industry, etc.). Algal biomass can be used in bioenergy because of their low fat content, which excludes the production of biodiesel (Person, 2011). In addition, marine algae are used in cosmetics for their moisturizing, nourishing, regenerating, slimming, soothing, remineralising, and other properties. Algal baths, with their nerve and muscle relaxing properties, anti-fatigue, tonic, invigorating and soothing properties are very effective in the medical and aesthetic field. For all these reasons, they are a natural therapy of choice to maintain the beauty of the skin, to significantly delay skin aging, etc. (Person, 2011).
Recently, much interest has been developed for the isolation of new bioactive compounds from marine algae because of their many beneficial effects on health (Oumaskour et al., 2013). Numerous reports show that marine algae present a broad range of biological activities such as antibacterial (Kavita et al., 2014), antifungal (Morales et al., 2006), antiviral (Plouguerne et al., 2013), anti-inflammatory and antioxidant (Mhadhebi et al., 2014), and anticancer (Duc Thinh et al., 2013). They are in fact a rich source of sulfated polysaccharides, which are known to have many biological activities including anticoagulant, gastroprotective, anti-inflammatory activities, and many others which give them an interest in pharmaceutical uses (Chaves et al., 2013).

\section{CONSLUSION}

The present study revealed that the two crude extracts prepared from the marine red algae Laurencia papillosa collected from the Lebanese coast are cytotoxic against the Jurkat human cancer cell line in a time and dose dependent manner, via the trypan blue exclusion assay. The IC50 values are $121.642 \mu \mathrm{g} / \mathrm{mL}$ and $57.77 \mu \mathrm{g} / \mathrm{mL}$ for the ethanol: water extract and the ethanol: chloroform extract, respectively after 72 hours of treatment.

L. papillosa appears to be an interesting and profitable red seaweed due to its anticancer activity against human leukemia cell lines Jurkat. Regarding this preliminary result, more studies are needed to demonstrate that L. papillosa crude extracts exhibit no cytotoxicity towards normal cells. Furthermore, the isolation and purification of new natural antitumor compounds of those algal extracts should be explored, and the examination of the mechanism of action of these compounds as well, (their effect on the cell cycle and their ability to induce apoptosis).

\section{ACKNOWLEDGMENTS}

Financial support and sponsorship: We deeply thank the Lebanese University for their valuable financial donation granted to us. We also thank Mrs. Feriale Srour for the English revision of the manuscript.

Conflict of Interests: There are no conflicts of interest.

\section{REFERENCES}

Alarif WM, Al-Lihaibi SS, Ayyad S-EN, Abdel-Rhman MH, Badria FA. Laurene-type sesquiterpenes from the Red Sea red alga Laurencia obtusa as potential antitumor-antimicrobial agents. European Journal of Medicinal Chemistry, 2012; 55:462-466.

Angawi RF, Alarif WM, Hamza RI, Badria FA, Ayyad S-EN. New Cytotoxic Laurene-, Cuparene-, and Laurokamurene-Type Sesquiterpenes from the Red Alga Laurencia obtusa. HCA, 2014; 97(10):1388-1395.

Cabioc'h JA. Guide des algues des mers d'Europe : Manche/Atlantique : Méditerranée. Delachaux et Niestlé. Neuchâtel, Paris; 1992.

Campos A, Souza CB, Lhullier C, Falkenberg M, Schenkel EP, Ribeiro-do-Valle RM, et al. Anti-tumour effects of elatol, a marine derivative compound obtained from red algae Laurencia microcladia. Journal of Pharmacy and Pharmacology, 2012; 64(8):1146-1154. 
Chaves L de S, Nicolau LAD, Silva RO, Barros FCN, Freitas ALP, Aragão KS, et al. Antiinflammatory and antinociceptive effects in mice of a sulfated polysaccharide fraction extracted from the marine red algae Gracilaria caudata. Immunopharmacol Immunotoxicol, 2013; 35(1):93-100.

Choi H-K, Choi YH, Verberne M, Lefeber AWM, Erkelens C, Verpoorte R. Metabolic fingerprinting of wild type and transgenic tobacco plants by $1 \mathrm{H}$ NMR and multivariate analysis technique. Phytochemistry, 2004; 65(7):857-864.

Du B, Zhong X, Liao X, Xu W, Zhou X, Xu S. A new antitumor arabinopyranoside from Laurencia majuscula induces G2/M cell cycle arrest. Phytother Res, 2010; 24(10):1447-1450.

Duc Thinh P, Menshova RV, Ermakova SP, Anastyuk SD, Ly BM, Zvyagintseva TN. Structural Characteristics and Anticancer Activity of Fucoidan from the Brown Alga Sargassum mcclurei. Mar Drugs, 2013; 11(5):1456-1476.

Esseily F, El Ezzy M, Gali-Muhtassib H, Safi S, Esseily J, DiaAssaf M, Lampronti I \& Saab A. The ethanol fraction from the stem of Berberis libanotica inhibits the viability of adult T cell leukemia. Minerva Biotecnologica, 2012; 24(4).

$\mathrm{Hu}$ Y, Xiong Q, Yang Y, Wang $\mathrm{H}$, Shu $\mathrm{C}, \mathrm{Xu} \mathrm{W}$, et al. Integrated analysis of gene expression and microRNA regulation in three leukemia-related lymphoblastic cell lines. Gene, 2015; 564(1):39-52.

Iliopoulou D, Mihopoulos N, Vagias C, Papazafiri P, Roussis V. Novel Cytotoxic Brominated Diterpenes from the Red Alga Laurencia obtusa. J Org Chem, 2003; 68(20):7667-7674.

Kandale, Ajit, A. K. Meena, M. M. Rao, P. Panda, and Ramesh Babu. Marine Algae: An Introduction, Food Value and Medicinal Uses. Journal of Pharmacy Research, 2011; 4(1): 123-127

Kavita K, Singh VK, Jha B. 24-Branched $\Delta 5$ sterols from Laurencia papillosa red seaweed with antibacterial activity against human pathogenic bacteria. Microbiological Research, 2014; 169(4):301-306.

Kim, M. C., S. Dharaneedharan, Y. G. Moon, D. H. Kim, H. J. Son, and M. S. Heo. Isolation and Identification of Oceanisphaera Sp. JJM57 from Marine Red Algae Laurencia Sp. (Ceramiales: Rhodomelaceae). The Korean Journal of Microbiology, 2013; 49 (1), 58 63

Kladi M, Xenaki H, Vagias C, Papazafiri P, Roussis V. New cytotoxic sesquiterpenes from the red algae Laurencia obtusa and Laurencia microcladia. Tetrahedron,2006; 62(1):182-189.

Lampronti I, Saab AM, Gambari R. Antiproliferative activity of essential oils derived from plants belonging to the Magnoliophyta division. Int J Oncol, 2006; 29(4):989-995.

Lhullier C, Falkenberg M, Ioannou E, Quesada A, Papazafiri P, Horta PA, et al. Cytotoxic halogenated metabolites from the Brazilian red alga Laurencia catarinensis. J Nat Prod, 2010; 73(1):27-32.

Makkar HPS, Tran G, Heuzé V, Giger-Reverdin S, Lessire M, Lebas F, et al. Seaweeds for livestock diets: A review. Animal Feed Science and Technology, 2016; 212:1-17.

Mhadhebi L, Mhadhebi A, Robert J, Bouraoui A. Antioxidant, Anti-Inflammatory and Antiproliferative Effects of Aqueous Extracts of Three Mediterranean Brown Seaweeds of the Genus Cystoseira. Iranian Journal of Pharmaceutical Research : IJPR, 2014; 13 (1): 207-220.

Mohamed S, Hashim SN, Rahman HA. Seaweeds: A sustainable functional food for complementary and alternative therapy. Trends in Food Science \& Technology, 2012; 23(2):83-96.

Morales JL, Cantillo-Ciau ZO, Sánchez-Molina I, Mena-Rejón GJ. Screening of Antibacterial and Antifungal Activities of Six Marine Macroalgae from Coasts of Yucatán Peninsula. Pharmaceutical Biology, 2006; 44(8):632-635.
Namvar F, Mohamad R, Baharara J, Zafar-Balanejad S, Fargahi F, Rahman HS. Antioxidant, Antiproliferative, and Antiangiogenesis Effects of Polyphenol-Rich Seaweed (Sargassum muticum). BioMed Research International, 2013; 2013:e604787.

Oumaskour K, Boujaber N, Etahiri S, Assobhei O. Antiinflammatory and anti-microbial activities of twenty three marine red algae from the coast of Sidi Bouzid ( El Jadida-Moroco. International Journal of Pharmacy and Pharmaceutical Sciences, 2013; 5(3).4.

Pacheco FC, Villa-Pulgarin JA, Mollinedo F, Martín MN, Fernández JJ, Daranas AH. New Polyether Triterpenoids from Laurencia viridis and Their Biological Evaluation. Mar Drugs, 2011; 9(11):22202235 .

Pieters R, Carroll WL. Biology and Treatment of Acute Lymphoblastic Leukemia. Pediatric Clinics, 2008; 55(1):1-20.

Plouguerne E, Souza LM de, Sassaki GL, Cavalcanti JF, Romanos MTV, da BAP, et al. Antiviral Sulfoquinovosyldiacylglycerols (SQDGs) from the Brazilian Brown Seaweed Sargassum vulgare. Marine Drugs, 2013;11(11):4628-4640.

Saab AM, Lampronti I, Grandini A, Borgatti M, Sacchetti G, Gambari R \& Guerrini A. Antiproliferative and Erythroid Differentiation Activities of Cedrus libani Seed Extracts against K562 Human Chronic Myelogenus Leukemia Cells. International Journal of Pharmaceutical \&amp; Biological Archives, 2011; 2(6):1744-1748.

Stein EM, Andreguetti DX, Rocha CS, Fujii MT, Baptista MS, Colepicolo P, et al. Search for cytotoxic agents in multiple Laurencia complex seaweed species (Ceramiales, Rhodophyta) harvested from the Atlantic Ocean with emphasis on the Brazilian State of Espírito Santo. Revista Brasileira de Farmacognosia, 2011; 21(2):239-243.

Vieira AP, Stein EM, Andreguetti DX, Colepicolo P, Ferreira $\mathrm{AM}$ da C. Preparation of silver nanoparticles using aqueous extracts of the red algae Laurencia aldingensis and Laurenciella sp. and their cytotoxic activities. The Journal of Applied Phycology, 2015; 1-8.

Zaleta-Pinet DA, Holland IP, Muñoz-Ochoa M, MurilloAlvarez JI, Sakoff JA, Altena IA van, et al. Cytotoxic Compounds from Laurencia Pacifica. Organic and Medicinal Chemistry Letters, 2014; 4(1):1-7.

\section{How to cite this article:}

Saab A, Tannoury M, Harb JEN, Makhlouf H, Assaf MD. In Vitro Cytotoxic Activity of Laurencia papillosa, Marine Red Algae from the Lebanese Coast. J App Pharm Sci, 2017; 7 (03): 175-179. 